Cite this: Soft Matter, 2013, 9, 2858

Received 5th October 2012

Accepted 3rd December 2012

DOI: $10.1039 / \mathrm{c} 2 \mathrm{sm} 27298 \mathrm{a}$

www.rsc.org/softmatter

\section{Co-assemblies of micelle-forming diblock copolymers and enzymes on graphite substrate for an improved design of biosensor systems $t$}

\author{
Larisa V. Sigolaeva, ${ }^{\text {*a }}$ Dmitry V. Pergushov, ${ }^{a}$ Christopher V. Synatschke, ${ }^{b}$ \\ Andrea Wolf, ${ }^{\mathrm{b}}$ Inna Dewald, ${ }^{\mathrm{C}}$ Ilya N. Kurochkin, ${ }^{\mathrm{a}}$ Andreas Fery ${ }^{\mathrm{c}}$ \\ and Axel H. E. Müller $\ddagger^{b}$
}

The adsorption of ionic amphiphilic diblock copolymers comprising a polycationic block, polybutadieneblock-poly(2-(dimethylamino)ethyl methacrylate) (PB- $b$-PDMAEMA); and its quaternized derivative (PB- $b$ PDMAEMAq) from aqueous media onto graphite-based surfaces was examined. Both diblock copolymers in aqueous solution form star-like micelles with a hydrophobic PB core and a cationic corona built up from either strong cationic PDMAEMAq or $\mathrm{pH}$-sensitive PDMAEMA. AFM experiments show that PB- $b$-PDMAEMAq micelles interact slightly with a graphite surface providing films with a low surface coverage. PB- $b$-PDMAEMA micelles adsorbed onto a graphite surface at $\mathrm{pH} \geq 7$ result in a more homogeneous coverage of the graphite surface by the diblock copolymer. The adsorption of two enzymes, tyrosinase (Tyr) and choline oxidase (ChO) on the graphite surface premodified with these diblock copolymers was also monitored by AFM and by electrochemical measurements of the enzymatic activities of PB- $b$-PDMAEMA-Tyr and PB- $b$-PDMAEMA-ChO films. A pronounced increase in the enzymatic activity of tyrosinase was observed with the increasing concentration of PB- $b$-PDMAEMA micelles in solution used for their depositions. Also, a pronounced increase in the enzymatic activities of both tyrosinase and choline oxidase was observed with the increasing $\mathrm{pH}$ of the deposition of the micelles from 2 to 10 . The enzymatic activity increases with the coverage of the graphite surface with the preadsorbed copolymer. Finally, the polymer-enzyme films were tested as biosensors for phenol (when tyrosinase was adsorbed) and choline (when choline oxidase was adsorbed) and their activity and stability were compared to already existing setups.

\section{Introduction}

Layer-by-layer (LbL) deposition of oppositely charged polyelectrolytes allows the formation of condensed and homogeneous multilayer films. ${ }^{\mathbf{1 - 4}}$ The technique has been generalized and expanded, beyond polyelectrolytes, to inorganic nanoparticles, ${ }^{5}$ polymeric micelles, ${ }^{6-10}$ dendrimers, ${ }^{11,12}$ carbon nanotubes, ${ }^{13}$ biological molecules, ${ }^{14,15}$ etc.

In terms of enzyme immobilization, LbL deposition represents a suitable preparative technique providing a controllable amount and spatial distribution of the biocatalyst. It is particularly preferable for the design and fabrication of bioanalytical

${ }^{a}$ Department of Chemistry, Lomonosov Moscow State University, 119991 Moscow, Russia.E-mail: lsigolaeva@genebee.msu.ru

${ }^{b}$ Makromolekulare Chemie II, Universität Bayreuth, 95440 Bayreuth, Germany

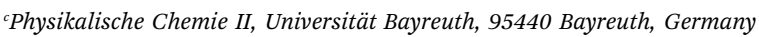

$\dagger$ Electronic supplementary information (ESI) available: operation stability of biosensors, more AFM images of PB- $b$-PDMAEMA-Tyr film under liquid. See DOI: $10.1039 / \mathrm{c} 2 \mathrm{sm} 27298 \mathrm{a}$

† Present address: Institut für Organische Chemie, Johannes Gutenberg-Universität Mainz, 55099 Mainz, Germany devices like biosensors and biochips. ${ }^{\mathbf{1 6 , 1 7}}$ The amount of enzyme incorporated into such polymer films and the strength of its binding to the respective polymer strongly affects the basic characteristics, such as activity and operation stability, of these bioanalytical surfaces.

The peculiarities of the adsorption of each new layer in the LbL technique are to a great extent determined by the state and structure of the preadsorbed polymer layers. ${ }^{18}$ The same rule seems to apply when the LbL technique is used for the polyelectrolyte-mediated adsorption of enzymes for their immobilization. ${ }^{19}$ Moreover, when LbL deposition is intended to be used for biosensor fabrication, in most cases one deals with the first stage of the LbL growth, the so-called precursor regime. ${ }^{20}$ The common reason is the requirement of a non-limited diffusion of an analyte and/or a product to/from an active surface. Therefore, both the choice of the solid support and the "prehistory" of the LbL deposition have a substantial influence on the resulting activity of a sensing surface.

Linear polycations like the most frequently used poly(diallyldimethylammonium chloride) and poly(allylamine), and linear polyanions such as poly(anetholsulfonic acid), etc. were 
typically used as components in already existing biosensor setups based on enzymes like horseradish peroxidase, ${ }^{21}$ glucose oxidase, ${ }^{22-25}$ lactate oxidase, ${ }^{22,23}$ cholesterol oxidase, ${ }^{26}$ choline oxidase,${ }^{27-30}$ acetylcholinesterase ${ }^{31}$ and tyrosinase.$^{32-35}$ However, current demand for their sensitivity and selectivity requires new matrices with increased adsorption and enhanced adhesion of a biomaterial.

Considerable progress in the controlled synthesis of welldefined polymers offers possibilities to design novel selfassembled polyionic species with non-linear architectures, yet unexplored in the field of biosensors. Among them are star-like micelles formed by ionic amphiphilic (ionic/non-ionic hydrophobic) diblock copolymers in aqueous media. ${ }^{36}$ Several research groups have studied the adsorption of diblock copolymer micelles onto planar surfaces, ${ }^{6-10,37-40}$ taking into account the type and hydrophobicity of a substrate ${ }^{\mathbf{4 1 , 4 2}}$ and adsorption conditions. ${ }^{\mathbf{4 3 4}}$ To the best of our knowledge, there are no data on the adsorption of amphiphilic diblock copolymers onto a graphite substrate and LbL biosensors based on such types of polyelectrolytes have not been developed so far either.

The main idea of this study is to use micelles formed by diblock copolymers as novel polymeric components to deposit the first polymeric layer onto a conductive graphite support, which can further electrostatically bind electrochemically active enzymes in LbL-constructed sensor coatings. Due to the presence of hydrophobic non-ionic blocks in the micelles of ionic amphiphilic diblock copolymers, their adsorption onto a relatively hydrophobic graphite substrate is thought to provide a considerably more uniform adhesive covering of the latter. The adsorption of an increased amount of enzyme is expected, resulting in the higher enzymatic activity of the whole films.

This paper describes the interaction of star-like micelles of ionic amphiphilic diblock copolymers with a polycationic block, polybutadiene-block-poly(2-(dimethylamino)ethyl methacrylate), (PB- $b$-PDMAEMA), and the same polymer exhaustively quaternized with dimethylsulfate (PB- $b$-PDMAEMAq) with a hydrophobic graphite surface. The subsequent adsorption of two enzymes, tyrosinase (Tyr) and choline oxidase (ChO), on the graphite surface, premodified with such diblock copolymers, was also studied. The structure and properties of the nanosized polymer-enzyme films assembled on the graphite surface were examined in dependence of the nature of the polycationic block and the adsorption conditions. Finally, we tested the polymerenzyme films as biosensors for choline and phenol in their activity and stability as well as compared them to already existing setups.

\section{Experimental part}

\section{Materials}

Choline oxidase (ChO) (from Alcaligenes sp., E.C. 1.1.3.17, activity $11.6 \mathrm{U} \mathrm{mg}^{-1}$ ) from Fluka (Germany), and tyrosinase (Tyr) (from mushroom, E.C. 1.14.18.1, activity $3900 \mathrm{U} \mathrm{mg}^{-1}$ for L-tyrosine) from Sigma (Germany) were used as electrochemically active enzymes for the preparation of sensor surfaces. Potassium permanganate (Chimmed, Russia) and manganese acetate tetrahydrate (Acros, Belgium) were applied for manganese dioxide sol solution preparation. 4-(2-Hydroxyethyl)-1-piperazineethanesulfonic acid (HEPES), silver trifluoroacetate (99.99\%), phenol and choline were purchased from Sigma-Aldrich. Trans-2-[3-(4-tert-butylphenyl)-2-methyl-2propenylidene] malononitrile (DCTB, 99.0\%) was purchased from Fluka. Highly oriented pyrolytic graphite (HOPG) with an area of about $50 \mathrm{~mm}^{2}$ was purchased from NT-MDT (Zelenograd, Russia). Dimethylsulfate (Aldrich, 99\%) was used as received. THF (Sigma-Aldrich, p.a. quality) was first distilled over $\mathrm{CaH}_{2}$ followed by a distillation over potassium and stored under $\mathrm{N}_{2}$ before use. 2-( $N, N$-Dimethylamino)ethyl methacrylate (DMAEMA, Aldrich, 98\%) was degassed three times by freezepump-thaw cycles, before trioctylaluminum was added and stirred for $1 \mathrm{~h}$ under the exclusion of light. Subsequently, DMAEMA was condensed into a storage ampoule under low pressure and kept frozen and under $\mathrm{N}_{2}$ until further use. Butadiene (Messer-Griesheim) was purified by passing through columns filled with molecular sieves $(4 \AA)$ and basic aluminum oxide, before condensation into a glass reactor and storage over dibutylmagnesium. For purification 1,1-diphenylethylene (Aldrich, 97\%) was first stirred with sec-butyllithium (sec-BuLi) under $\mathrm{N}_{2}$ before distillation. sec-BuLi (Aldrich, 1.4 M in cyclohexane), dibutylmagnesium (Aldrich, $1 \mathrm{M}$ in heptane), trioctylaluminum (Aldrich, $25 \mathrm{wt} \%$ in hexanes) and dioxane (Fisher Scientific, p.a. quality) were used as received. For dialysis, membranes made from regenerated cellulose (Spectrum Laboratories, Spectra/Por MWCO 6-8 kDa and $3.5 \mathrm{kDa}$ ) were used. All other chemicals, salts, and buffer components were of analytical grade and used without further purification. All aqueous solutions were prepared either from Milli-Q water or buffer solutions in the range $\mathrm{pH} 2$ to $\mathrm{pH} 10$ (VWR, AVS Titrinorm) with an ionic strength ca. $0.05 \mathrm{M}$. Water was purified with a Milli-Q water purification system by Millipore.

\section{Synthesis of PB-b-PDMAEMA diblock copolymer}

Polymerizations were carried out in a thermostated laboratory autoclave (Büchi) under a dry nitrogen atmosphere. Synthesis of the block copolymer was performed with THF as the solvent by sequential living anionic polymerization at low temperatures. To $600 \mathrm{~mL}$ of THF, $6 \mathrm{~mL}$ of sec-BuLi was added at $-20^{\circ} \mathrm{C}$ and stirred overnight to form alkoxides, which help to stabilize the living chain ends during the polymerization. ${ }^{45}$ Then, at $-70{ }^{\circ} \mathrm{C}$ sec-BuLi $(0.677 \mathrm{~mL}, 0.947 \mathrm{mmol})$ was added to the solution followed by fast addition of butadiene $(15.5 \mathrm{~mL}, 10.23 \mathrm{~g}, 0.189$ mol), which had been condensed into a precooled burette $\left(-20{ }^{\circ} \mathrm{C}\right)$. The mixture was allowed to heat to $-50{ }^{\circ} \mathrm{C}$ and stirred for $17 \mathrm{~h}$, before 1,1-diphenylethylene $(0.85 \mathrm{~mL}, 4.81 \mathrm{mmol})$ was added and stirred for another $2 \mathrm{~h}$ to end cap the living chain ends. Finally, DMAEMA (30.69 g, $0.195 \mathrm{~mol}$ ) was injected with a nitrogen purged glass syringe into the reactor. The polymerization was stirred for $2 \mathrm{~h}$ at $-50{ }^{\circ} \mathrm{C}$ and another $1 \mathrm{~h}$ at $-35^{\circ} \mathrm{C}$ to ensure complete conversion before the polymerization was quenched through the addition of $200 \mu \mathrm{L}$ of previously degassed methanol. Purification was achieved by dialysis against THF and subsequently against a 2/1 mixture of dioxane and water and the final polymer ( $35.3 \mathrm{~g}$ ) was obtained after lyophilization. 


\section{Quaternization of the PDMAEMA block}

Quaternization was done in accordance with ref. 46. For quaternization $1 \mathrm{~g}$ lyophilized PB- $b$-PDMAEMA (0.745 $\mathrm{g}$ DMAEMA $=$ $4.379 \mathrm{mmol}$ ) was dissolved in $250 \mathrm{~mL}$ dioxane in a round bottom flask equipped with a magnetic stirrer. Then, the polymer solution was treated with $0.9 \mathrm{~mL}$ dimethylsulfate $(1.2 \mathrm{~g}$, 9.48 mmol, 2 equivalents to nitrogen of DMAEMA), sealed under a nitrogen atmosphere and stirred at $40{ }^{\circ} \mathrm{C}$ for 2 days. For purification the polymer was dialyzed to Milli-Q water for at least 5 days with regular exchange of the dialysis solution using membranes made from regenerated cellulose (Spectrum Laboratories, Spectra/Por MWCO 6-8 kDa). $980 \mathrm{mg}$ quaternized PB- $b$-PDMAEMA was obtained after lyophilization. Quantitative quaternization of the nitrogen groups was confirmed by ${ }^{1} \mathrm{H}$ NMR in deuterated water.

\section{${ }^{1} \mathrm{H}$ Nuclear magnetic resonance (NMR) spectroscopy}

${ }^{1} \mathrm{H}$ NMR spectra were recorded on a Bruker Ultrashield 300 spectrometer at an operating frequency of $300 \mathrm{MHz}$. $\mathrm{CDCl}_{3}$ was used as solvent with tetramethylsilane as internal standard, if not indicated otherwise.

\section{MALDI-ToF mass spectrometry (MALDI-ToF MS)}

MALDI-ToF MS analysis was performed on Bruker Reflex III apparatus equipped with a $\mathrm{N}_{2}$ laser $(\lambda=337 \mathrm{~nm})$ in linear mode at an acceleration voltage of $20 \mathrm{kV}$. DCTB was used as a matrix material and AgTFA as an ionization agent. Samples were prepared by the dried droplet method with THF as solvent by mixing separately dissolved matrix $\left(20 \mathrm{mg} \mathrm{mL}^{-1}\right)$, analyte $\left(10 \mathrm{mg} \mathrm{mL}^{-1}\right)$, and salt $\left(10 \mathrm{mg} \mathrm{mL}^{-1}\right)$ in a ratio of $20: 5: 1(\mathrm{v} / \mathrm{v})$ and applying approximately $1 \mu \mathrm{L}$ of the final solution to the target plate.

\section{Gel permeation chromatography (GPC)}

For the PB precursor homopolymer, a Waters instrument calibrated with narrowly distributed $1,4-\mathrm{PB}$ standards at $40{ }^{\circ} \mathrm{C}$ and equipped with four PSS-SDV gel columns ( $5 \mathrm{~mm}$ ) with a porosity range from $10^{2}$ to $10^{5} \AA$ (PSS, Mainz, Germany) was used together with a differential refractometer and a UV detector at $254 \mathrm{~nm}$. Measurements were performed in THF with a flow rate of $1 \mathrm{~mL} \mathrm{~min}^{-1}$ using toluene as internal standard. Experiments for the block copolymer containing DMAEMA were performed on a separate Waters instrument calibrated with narrowly distributed polystyrene standards. Four PSS-SDV gel columns (5 mm) with a porosity range from $10^{2}$ to $10^{4} \AA$ (PSS, Mainz, Germany) were used together with a differential refractometer and a UV detector at $254 \mathrm{~nm}$. Measurements were performed in THF with additional $0.25 \mathrm{wt} \%$ tetrabutylammonium bromide as the eluent and a flow rate of $0.5 \mathrm{~mL} \mathrm{~min}^{-1}$.

\section{Polymer characterization}

After the polymerization of the first block, polybutadiene (PB), a small sample was withdrawn from the reaction and the molecular weight determined by GPC $\left(\mathrm{M}_{\mathrm{n}, \mathrm{GPC}}=13500\right.$; $\left.\mathrm{PDI}_{\mathrm{GPC}}=1.03\right)$ and MALDI-ToF-MS ( $\mathrm{M}_{\mathrm{n}, \mathrm{MALDI}}=13$ 400;
$\mathrm{PDI}_{\text {MALDI }}=1.01$ ), which is in good agreement and corresponds to a number-average degree of polymerization of 250 for the first block. The overall composition of the diblock copolymer was then determined with ${ }^{1} \mathrm{H}$ NMR to be $25.5 \mathrm{wt} \% \mathrm{~PB}$ and $74.5 \mathrm{wt} \%$ PDMAEMA, with a fraction of $1,2-\mathrm{PB}$ of $90 \%$. The GPC measurement of the diblock copolymer showed a bimodal distribution with some terminated PB homopolymers of $13 \mathrm{wt} \%$ of the total polymer sample and an overall PDI of 1.45. The sample is therefore a mixture of $\mathrm{PB}_{250}$ homopolymer and $\mathrm{PB}_{250^{-}}$ $b$-PDMAEMA ${ }_{507}$. Detailed characterization from MALDI-ToF MS and two GPC systems (THF-GPC with PB standards and saltTHF-GPC with polystyrene standards) is given in the following:

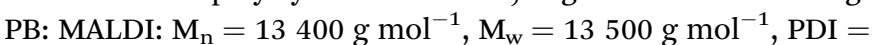
1.01; GPC (THF): $M_{n}=13500 \mathrm{~g} \mathrm{~mol}^{-1}, \mathrm{M}_{\mathrm{w}}=13900, \mathrm{PDI}=1.03$; GPC (salt-THF): $M_{\mathrm{n}}=22300 \mathrm{~g} \mathrm{~mol}^{-1}, \mathrm{M}_{\mathrm{w}}=24600 \mathrm{~g} \mathrm{~mol}^{-1}$, PDI = 1.10; PB-DPE: MALDI: $\mathrm{M}_{\mathrm{n}}=14000 \mathrm{~g} \mathrm{~mol}^{-1}, \mathrm{M}_{\mathrm{w}}=14200$ $\mathrm{g} \mathrm{mol}^{-1}$, PDI = 1.02; GPC (THF): $\mathrm{M}_{\mathrm{n}}=13700 \mathrm{~g} \mathrm{~mol}^{-1}, \mathrm{M}_{\mathrm{w}}=$ 14000, PDI $=1.02 ;$ GPC (salt-THF): $M_{n}=24200 \mathrm{~g} \mathrm{~mol}^{-1}, \mathrm{M}_{\mathrm{w}}=$ $27100 \mathrm{~g} \mathrm{~mol}^{-1}$, PDI $=1.12$; PB-DPE-PDMAEMA: GPC (saltTHF): $\mathrm{M}_{\mathrm{n}}=66500 \mathrm{~g} \mathrm{~mol}^{-1}, \mathrm{M}_{\mathrm{w}}=96700 \mathrm{~g} \mathrm{~mol}^{-1}, \mathrm{PDI}=1.45$.

\section{Adsorption experiments}

For AFM imaging of the polymer and polymer-enzyme films, the freshly cleaved HOPG was used (as slices of about $5 \mathrm{~mm} \times$ $10 \mathrm{~mm}$ ). For electrochemical enzymatic activity assay of the polymer-enzyme films, screen-printed electrodes (SPEs) were fabricated on a poly(vinyl chloride) substrate of $0.2 \mathrm{~mm}$ thickness by means of a conductive graphite paste (Gwent, UK) screen-printed by a semiautomated machine Winon (model WSC-160B, China) with a 200 mesh screen stencil. Each SPE consisted of a round-shaped working area (3 $\mathrm{mm}$ diameter), a conductive track $(30 \mathrm{~mm} \times 1.5 \mathrm{~mm})$, and a square extremity $(3$ $\mathrm{mm} \times 7 \mathrm{~mm}$ ) for electrical contact. When necessary, HOPG/ SPEs were premodified by a peroxide-sensitive $\mathrm{MnO}_{2}$ layer (for details see (ref. 47)). Briefly, a freshly prepared $\mathrm{MnO}_{2}$ sol solution was formed via 1 : 1 mixing of $0.25 \mathrm{mM} \mathrm{KMnO}_{4}$ and 0.375 $\mathrm{mM}$ of $\mathrm{Mn}\left(\mathrm{CH}_{3} \mathrm{COO}\right)_{2}$ and shaking for $5 \mathrm{~min}$. Then the substrate was covered by $\mathrm{MnO}_{2}$ sol solution followed by drying at room temperature for $40 \mathrm{~min}$, rinsing with Milli-Q water $\left(18.2 \mathrm{M} \Omega \mathrm{cm}^{-1}\right)$ and drying at $60{ }^{\circ} \mathrm{C}$ for $1 \mathrm{~h}$. The $10 \mathrm{~g} \mathrm{~L}^{-1}$ stock solutions of PB- $b$-PDMAEMA or PB- $b$-PDMAEMAq micelles were prepared in $\mathrm{pH} 7.0$ buffer by direct dissolution of the diblock copolymer. From the stock samples, solutions with different $\mathrm{pH}$ were prepared via dialysis against the corresponding buffer using membranes of regenerated cellulose (Spectrum Laboratories, Spectra/Por, Roth) with MWCO $3.5 \mathrm{kDa}$. When lower concentrations were necessary they were prepared by a direct dilution of dialysates with the same buffer media. Tyrosinase was prepared in $1 \times 10^{-4} \mathrm{M}$ in $0.05 \mathrm{M}$ sodium phosphate buffer (pH 7.0) and choline oxidase was prepared in $5 \times 10^{-5} \mathrm{M}$ in 0.05 M HEPES with $0.03 \mathrm{M} \mathrm{KCl} \mathrm{(pH} \mathrm{7.5).} \mathrm{Enzyme} \mathrm{stock} \mathrm{solutions}$ were stored at $+4{ }^{\circ} \mathrm{C}$ until further use. The micelles were adsorbed onto substrates via the dip coating method. After 1 hour the substrate was rinsed with Milli-Q water and dried with a stream of air. Enzymes were adsorbed in a similar way for 10 min followed by rinsing with Milli-Q water and drying with a 
stream of air. To prevent a loss of enzymatic activity, the SPEs covered by polymer-enzyme films were stored at $+4{ }^{\circ} \mathrm{C}$ until further use.

\section{Electrochemical assay}

Electrochemical experiments were performed at ambient temperature in a one-compartment electrochemical cell with stirring (volume of $1 \mathrm{~mL}$ ) using a two electrode configuration. A SPE covered by polymer-enzyme film with an active surface area of $0.049 \mathrm{~cm}^{2}$ served as the working electrode and $\mathrm{Ag} / \mathrm{AgCl}$ (with length of $1 \mathrm{~cm}$, diameter of $3 \mathrm{~mm}$, and surface area of $1.03 \mathrm{~cm}^{2}$ ) was used as a reference electrode. A micro-potentiostate IPCMicro (Kronas Ltd., Russia) used for electrochemical measurements was interfaced with a PC and electrochemical parameters were controlled by micro-potentiostate software. The activity of the tyrosinase films (Scheme 1(A)) was measured in $50 \mathrm{mM}$ sodium phosphate buffer with $100 \mathrm{mM} \mathrm{NaCl} \mathrm{(pH} \mathrm{7.0),} \mathrm{by}$ recording the current arising in response to the addition of phenol (in the range $10^{-6} \mathrm{M}$ to $10^{-5} \mathrm{M}$ depending on the sensor activity). Reductive current is generated due to $o$-quinone reduction at an applied potential $(-150 \mathrm{mV} v s$. $\mathrm{Ag} / \mathrm{AgCl})$, and is directly proportional to the tyrosinase activity. The activity of the choline oxidase films (Scheme 1(B)) was measured in $50 \mathrm{mM}$ HEPES buffer with $30 \mathrm{mM} \mathrm{KCl} \mathrm{(pH} \mathrm{7.5),} \mathrm{by} \mathrm{recording} \mathrm{the} \mathrm{current}$ arising in response to the addition of choline $\left(10^{-4} \mathrm{M}\right)$. Oxidative current is generated due to hydrogen peroxide oxidation at an applied potential $(+480 \mathrm{mV}$ vs. $\mathrm{Ag} / \mathrm{AgCl})$ and is directly proportional to the choline oxidase activity. The analytical signal of the enzyme-based electrodes was determined as a value of steady-state baseline current change (the difference between an average value of steady-state baseline current before and after analyte addition). Each electrochemical result was represented as mean $\pm \mathrm{SD}$ calculated in each case on the basis of at least three measurements obtained for at least three electrodes.

\section{Atomic force microscopy (AFM)}

AFM images were taken with a commercial AFM (DI Dimension 3100 Metrology ${ }^{\mathrm{TM}}$ ) operating in TappingMode ${ }^{\mathrm{TM}}$ and using $\mathrm{Si}_{3} \mathrm{~N}_{4}$ cantilevers (OMCLAC160TS, Olympus) with a typical spring constant of $42 \mathrm{~N} \mathrm{~m}^{-1}$, a typical resonance frequency of $300 \mathrm{kHz}$, and a tip radius less than $7 \mathrm{~nm}$. For imaging, light tapping (ratio of set point amplitude to free amplitude $\sim 0.9$ ) was applied. Each AFM result was presented as a typical image chosen on the basis of at least three uniform-sized images obtained from different places of each AFM sample. Images were analyzed using the NanoScope Analysis software version 1.20.
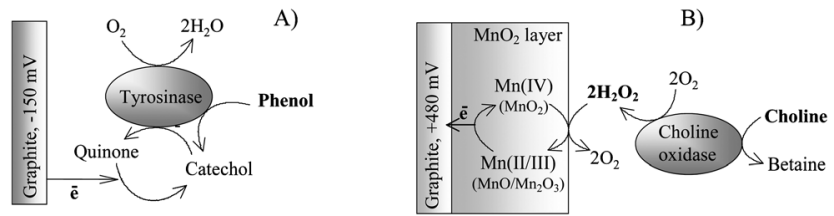

Scheme 1 Principle of amperometrical analysis of tyrosinase activity (biosensor for phenol) (A) and choline oxidase activity (biosensor for choline) (B).
AFM measurements in liquid were performed with a Dimension $^{\mathrm{TM}} 3100$ NanoScope $^{\circledR}$ controller V operating in TappingMode ${ }^{\mathrm{TM}}$. The AFM was equipped with a direct drive fluid probe holder (DTFML-DDHE) and cantilevers (SNL-10, Bruker) with a spring constant of $\sim 0.06 \mathrm{~N} \mathrm{~m}^{-1}$ and a resonance frequency of $12-24 \mathrm{kHz}$ were used.

\section{Cryogenic transmission electron microscopy (cryo-TEM)}

For cryo-TEM studies, a drop $(\sim 2 \mu \mathrm{L})$ of the sample solution $(c=$ $0.25 \mathrm{wt} \%$ ) was placed on a plasma-treated lacey carbon-coated copper TEM grid (200 mesh, Science Services, Münich, Germany), then most of the liquid was removed with blotting paper, leaving a thin film stretched over the grid holes. The specimens were instantly vitrified by rapid immersion into liquid ethane in a temperature-controlled freezing unit (Zeiss Cryobox, Zeiss NTS GmbH, Oberkochen, Germany) and cooled to approximately $90 \mathrm{~K}$. The temperature was monitored and kept constant in the chamber during all of the preparation steps. After freezing the specimens, they were inserted into a cryo-transfer holder (CT3500, Gatan, Münich, Germany) and transferred to a Zeiss EM922Omega instrument (Carl Zeiss Microscopy GmbH, Jena). Examinations were carried out at temperatures around $90 \mathrm{~K}$. The transmission electron microscope was operated at an acceleration voltage of $200 \mathrm{kV}$. Zeroloss filtered images $(\Delta E=0 \mathrm{eV})$ were taken under reduced dose conditions. All images were registered digitally by a bottommounted CCD camera system (Ultrascan 1000, Gatan), combined, and processed with a digital imaging processing system (Gatan Digital Micrograph 1.82) and UTHSCSA Image Tool 3.00.

\section{Contact angle (CA) measurements}

Static CAs on flat substrates were derived from drop shape analysis on a Dataphysics OCA20 at room temperature. CAs were measured with Millipore water as a probe liquid. A drop of $9 \mu \mathrm{L}$ was placed on the substrate (HOPG or SPE) covered by a film studied. Measurements were performed immediately after drop deposition to avoid water evaporation. The CA measurements were repeated 5-6 times on different locations and the values were subsequently averaged.

\section{Nanoparticle tracking analysis (NTA)}

The samples were diluted to a concentration suitable for analysis with $50 \mathrm{mM}$ sodium phosphate buffer $\mathrm{pH} 7.0$ that was primarily filtered 3 times through $200 \mathrm{~nm}$ Millipore Nylon filters, then 3 times through $20 \mathrm{~nm}$ polystyrene Millipore filters. All measurements were performed on an instrument manufactured by Nanosight NS500 (Salisbury, UK). The diluted sample was injected into the sample chamber equipped with a $640 \mathrm{~nm}$ diode laser. The software used for capturing and analyzing the data was the NTA 2.0 Build 127 . The samples were measured for $60 \mathrm{~s}$ with a manual shutter and gain adjustments. For each sample the measurement was repeated 10 times. Again, the buffer was also tested to ensure no nanoparticle contamination. After capture, the size for the individual particles was determined using NTA software. 


\section{Results and discussion}

\section{Self-assembly of diblock copolymers in solution}

In this study we used a linear diblock copolymer of polybutadiene and poly(2-(dimethylamino)ethyl methacrylate) PB- $b$ PDMAEMA, and the same polymer quaternized with dimethylsulfate PB- $b$-PDMAEMAq (the number-average degrees of polymerization of the PB and PDMAEMA are 250 and 507, respectively). The chemical structures of the diblock copolymers used are shown in Fig. 1(A).
Firstly, the self-assembly of the ionic amphiphilic diblock copolymers in aqueous media was examined at $\mathrm{pH}$ 7.0. Nanoparticle tracking analysis (NTA) shows the presence of scattering particles in aqueous media with an average diameter of $165 \mathrm{~nm}$ for PB- $b$-PDMAEMAq and $355 \mathrm{~nm}$ for PB- $b$-PDMAEMA (Fig. 1(B)). The obtained results clearly indicate the presence of large particles in aqueous media. It is reasonable to assume that both copolymers form star-like micelles. These micelles contain a hydrophobic PB core and a cationic corona built up from either quaternized PDMAEMAq or pH-dependent PDMAEMA
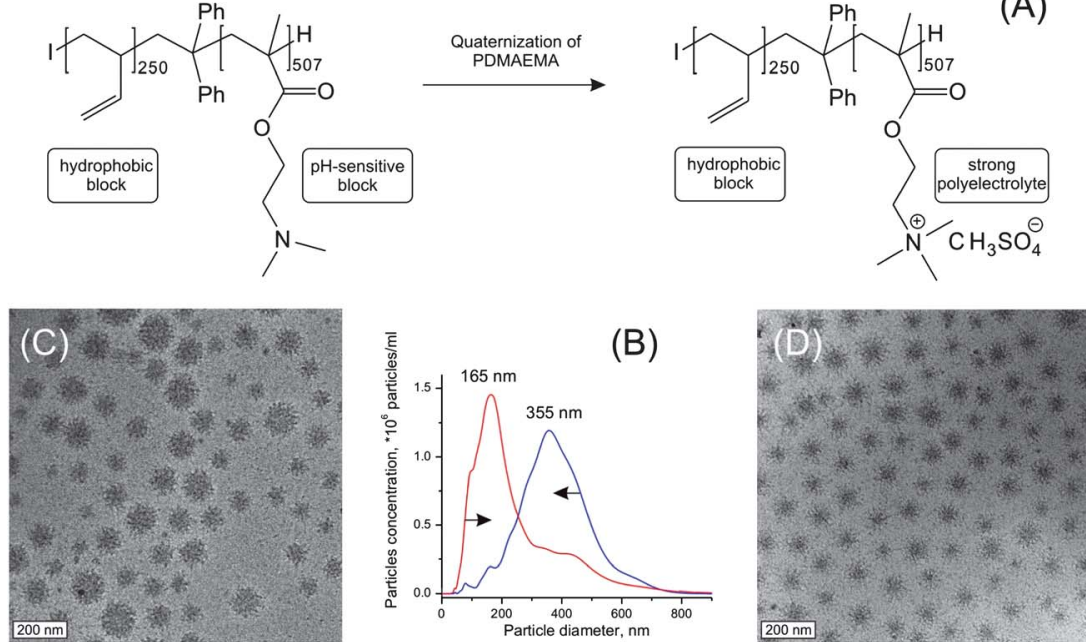

Fig. 1 Chemical structures of the diblock copolymers (A), NTA plot for PB- $b$-PDMAEMAq and PB- $b$-PDMAEMA micelles in aqueous solution $\left(c=5.0 \times 10^{-5} \mathrm{~g} \mathrm{~L}{ }^{-1}\right)$ at $\mathrm{pH}$ 7.0 (B), and cryo-TEM micrographs of PB-b-PDMAEMA (C) and PB-b-PDMAEMAq (D) in aqueous solution $\left(c \approx 2.5 \mathrm{~g} \mathrm{~L}^{-1}\right)$ at $\mathrm{pH} 7.0$.

(A) PB-b-PDMAEMAq

$0.1 \mathrm{~g} / \mathrm{L}$

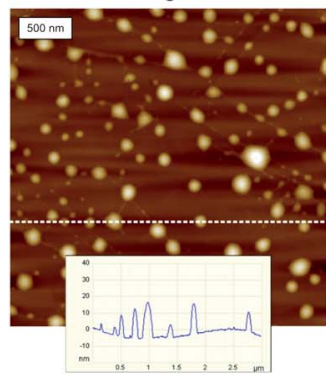

(D) PB-b-PDMAEMA

$0.1 \mathrm{~g} / \mathrm{L}$

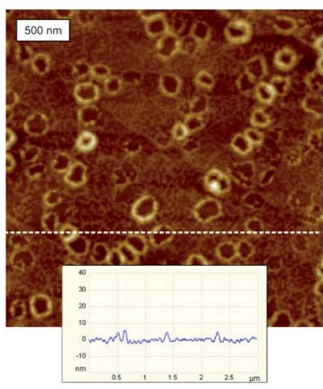

(B) PB- $b$-PDMAEMAq $1.0 \mathrm{~g} / \mathrm{L}$

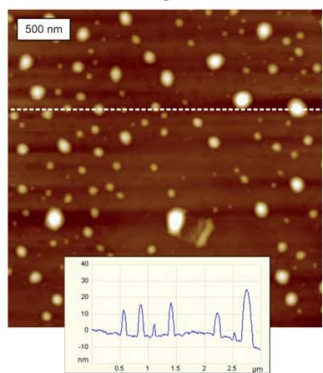

(E) PB-b-PDMAEMA $1.0 \mathrm{~g} / \mathrm{L}$



(C) PB-b-PDMAEMAq

$5.0 \mathrm{~g} / \mathrm{L}$

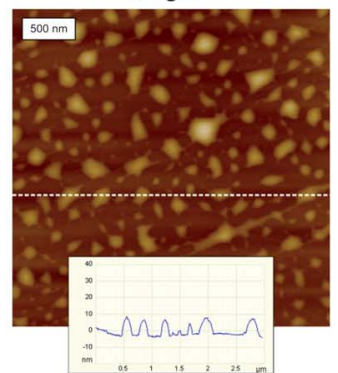

(F) PB-b-PDMAEMA

$5.0 \mathrm{~g} / \mathrm{L}$



Fig. 2 A series of $3 \times 3 \mu \mathrm{m}$ AFM height images of PB-b-PDMAEMAq (A-C) and PB-b-PDMAEMA (D-F) adsorbed on HOPG at pH 7.0 from 0.1 (A and D), 1.0 (B and E), and 5.0 ( $C$ and F) $\mathrm{g} \mathrm{L}^{-1}$ solutions for $1 \mathrm{~h}$. The height range is $50 \mathrm{~nm}$ for $\mathrm{A}-\mathrm{C}$ and $20 \mathrm{~nm}$ for $\mathrm{D}-\mathrm{F}$ images. Cross-sections were taken at the places indicated by the dashed lines. 
(A) PB-b-PDMAEMAq

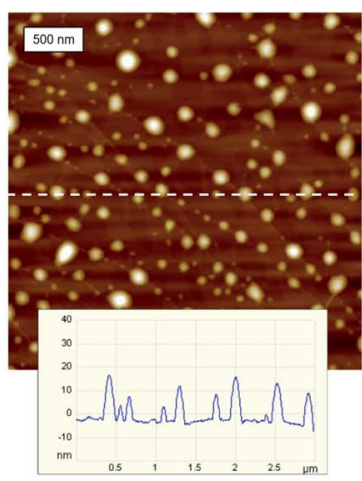

(C) PB-b-PDMAEMA

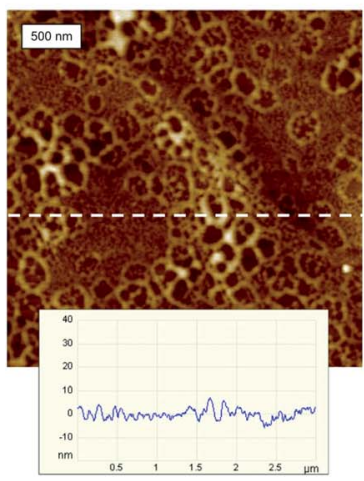

(B) PB-b-PDMAEMAq/Tyr

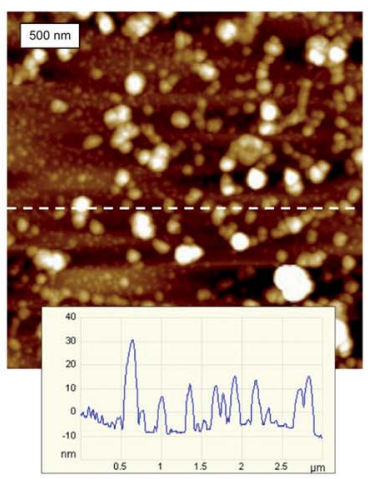

(D) PB-b-PDMAEMA/Tyr

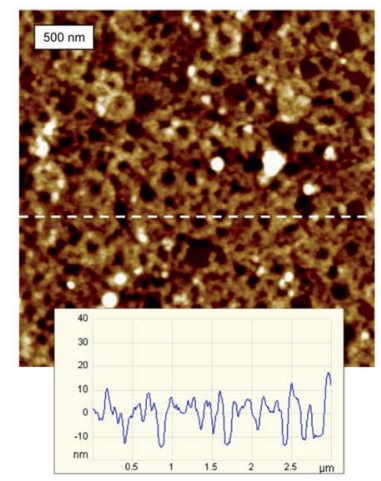

Fig. $33 \times 3 \mu \mathrm{m}$ AFM height images of polymer-enzyme films PB- $b$-PDMAEMAq (A), PB-b-PDMAEMAq-Tyr (B), PB-b-PDMAEMA (C), and PB-b-PDMAEMA-Tyr (D) adsorbed on HOPG at pH 7.0. The adsorption time for polymer and enzyme was 1 $\mathrm{h}$ and $10 \mathrm{~min}$, respectively. The concentration of the diblock copolymers was $1 \mathrm{~g}$ $\mathrm{L}^{-1}$, the concentration of the enzyme was $2 \times 10^{-4} \mathrm{M}$. The height range was 50 $\mathrm{nm}$ for $\mathrm{A}$ and $\mathrm{B}$ and $20 \mathrm{~nm}$ for $C$ and $D$ images. Cross-sections were taken at the places indicated by the dashed lines.

Table 1 Contact angles (CAs) for polymer and polymer-enzyme films adsorbed onto HOPG and SPE at $\mathrm{pH} 7.0^{\mathrm{a}}$

\begin{tabular}{|c|c|c|}
\hline \multirow[b]{2}{*}{ Film composition } & \multicolumn{2}{|c|}{$\begin{array}{l}\text { Static CA } \\
(\text { mean } \pm \mathrm{SD}, n=6-8)\end{array}$} \\
\hline & HOPG & SPE \\
\hline Naked surface & $85.1 \pm 4.3$ & $133.3 \pm 0.8$ \\
\hline Treated by the buffer solution, $\mathrm{pH} 7.0$ & $77.0 \pm 2.0$ & $125.3 \pm 2.8$ \\
\hline Covered by PB- $b$-PDMAEMA film & $81.4 \pm 4.9$ & $101.0 \pm 2.3$ \\
\hline Covered by PB- $b$-PDMAEMA-Tyr film & $61.3 \pm 10.5$ & $32.1 \pm 13.8$ \\
\hline Covered by PB- $b$-PDMAEMAq film & $78.9 \pm 5.2$ & $82.8 \pm 10.8$ \\
\hline Covered by PB- $b$-PDMAEMAq-Tyr film & $74.1 \pm 2.2$ & $57.0 \pm 11.7$ \\
\hline \multicolumn{3}{|c|}{$\begin{array}{l}{ }^{a} \text { Conditions: the diblock copolymers and enzyme were adsorbed at } \mathrm{pH} \\
7.0 \text { for } 1 \mathrm{~h} \text { and } 10 \mathrm{~min} \text {, respectively. The concentration of the diblock } \\
\text { copolymers was } 0.5 \mathrm{~g} \mathrm{~L}^{-1} \text {, the concentration of the enzyme was } 2 \times \\
10^{-4} \mathrm{M} \text {. }\end{array}$} \\
\hline
\end{tabular}

blocks. Although the polymer contains $13 \mathrm{wt} \%$ of PB homopolymer, it is reasonable to assume that it will be completely incorporated into the core of the formed micelles. Thus, the



Fig. 4 Enzymatic (electrochemical) activity of PB-b-PDMAEMAq-Tyr (open symbols) and PB-b-PDMAEMA-Tyr (solid symbols) films versus the concentration of the diblock copolymer, at which its adsorption was carried out. Adsorption of the copolymers: $0.1-10 \mathrm{~g} \mathrm{~L}^{-1}$ PB- $b$-PDMAEMAq or PB- $b$-PDMAEMA solutions in $\mathrm{pH} 7.0$ buffer for $1 \mathrm{~h}$. Adsorption of the enzyme: $2 \times 10^{-4} \mathrm{M}$ tyrosinase solution in $0.05 \mathrm{M}$ of sodium phosphate $(\mathrm{pH} 7.0)$ for $10 \mathrm{~min}$.

PDMAEMA and PDMAEMAq corona will not be affected. From a comparison of the data for both diblock copolymers, one can see that larger micelles are formed at $\mathrm{pH} 7$ for the non-quaternized copolymer.

The core-corona structure of the micelles was visualized by cryogenic transmission electron microscopy (cryo-TEM). Fig. 1(D) shows a cryo-TEM micrograph of the PB- $b$-PDMAEMAq micelles at $\mathrm{pH} 7$ as objects with spherical shape and rather narrow size distribution. A darker hydrophobic PB core with a mean diameter of $36 \pm 7 \mathrm{~nm}$ (averaged value was obtained from approximately 120 micelles) is visible in the center of the objects. The water-soluble PDMAEMAq corona is only partially visible (in the vicinity of the PB core) in the cryo-TEM micrograph due to its lower electron contrast. Fig. 1(C) shows a cryoTEM micrograph of the PB- $b$-PDMAEMA micelles at $\mathrm{pH} 7$, which have a broad size distribution of $\mathrm{PB}$ cores with a mean diameter of $96 \pm 23 \mathrm{~nm}$ (averaged value was obtained from approximately 150 micelles). This difference can be explained by the different behavior of the PDMAEMA/PDMAEMAq blocks. Highly charged PDMAEMAq is characterized by a rather stretched conformation of the coronal blocks and a strong repulsion of the micelles from each other. Contrary to this, only about half of the monomer units of the PDMAEMA blocks are protonated at $\mathrm{pH} 7$ (PDMAEMA is a weak polybase with $\mathrm{p} K_{\mathrm{b}, \text { app }}=7.8$ (ref. 48)) leading to a shrinkage of the micellar corona, decreasing the strength of the repulsion among micelles and leading to their merging. An increase in the aggregation number for the micelles of the non-quaternized copolymer compared to the quaternized one, as can be seen from the increased core diameter, explains their larger size. ${ }^{49}$

\section{Surface assembly of diblock copolymer-enzyme films: concentration effect}

For all the adsorption experiments micelles were adsorbed by the dip coating method with an adsorption time of 1 hour. We suppose adsorption to reach saturation during this time, as it was examined in detail on a similar system in previous 
A)

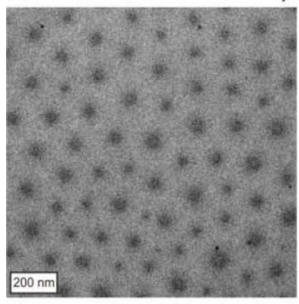

$\mathrm{pH} 3$

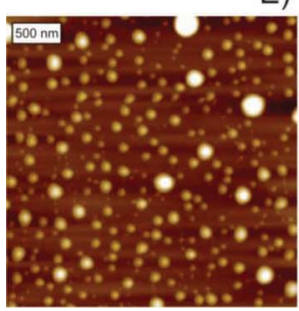

B)

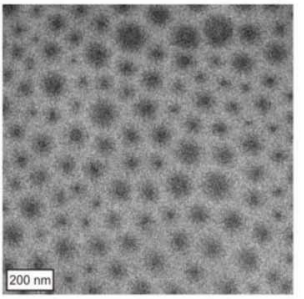

$\mathrm{pH} 6$

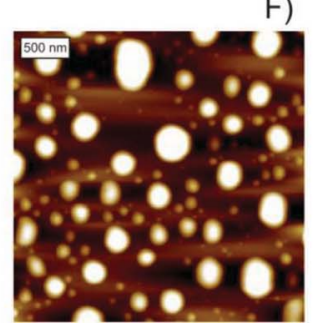

C)

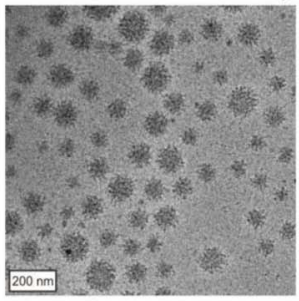

$\mathrm{pH} 7$

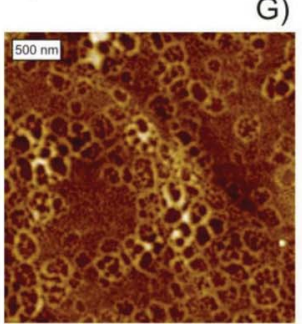

D)

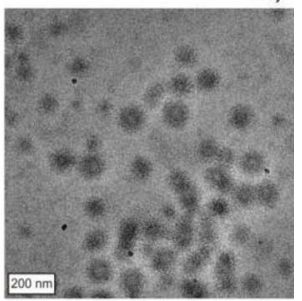

$\mathrm{pH} 10$

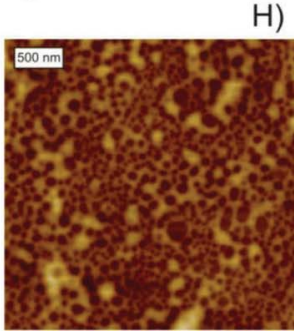

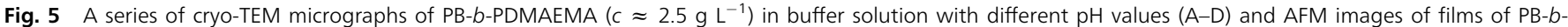

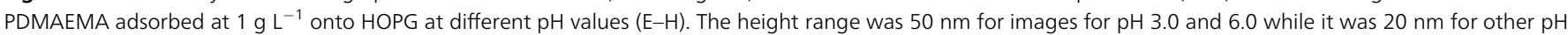
values. Scan size is $3 \times 3 \mu \mathrm{m}$

publications. ${ }^{\mathbf{5 0} 51}$ We used two types of hydrophobic graphitebased materials as conductive substrates. First, highly oriented pyrolytic graphite (HOPG) was used as a model system to study the adsorption characteristics. The surface of freshly cleaved HOPG is very smooth within a single terrace $\left(R_{\mathrm{a}}=2 \pm 1 \mathrm{~nm}\right)$ and relatively hydrophobic with an air contact angle (CA) value of $85.1 \pm 4.3$. Therefore, it is well suited for atomic force microscopy but not ideal for sensor applications. To design biosensors, we applied the graphite-based substrate attached to an inert support by the screen-printing technique mentioned below as a screen-printed electrode (SPE). A SPE is characterized by a high roughness of $86 \pm 2 \mathrm{~nm}$ and a high hydrophobicity $(\mathrm{CA}=133.3 \pm 0.8)$ to which the high roughness makes an additional contribution. Finally, two electrochemically active enzymes, tyrosinase and choline oxidase, were used as polyanionic components to be complexed with preadsorbed diblock copolymers also in a dip coating mode for $10 \mathrm{~min}$ at $\mathrm{pH} 7$ and at specified enzyme concentrations. The technique of biosensor preparation implies that each stage of adsorption was followed by stages of film washing by water (in order to remove any weakly adsorbed molecules) and drying in air (in order to stabilize the whole film and to improve its attachment to the substrate).

The films formed upon the adsorption of micelles of PB- $b$ PDMAEMA and its quaternized analogue, PB- $b$-PDMAEMAq, on a surface of HOPG were characterized by atomic force microscopy (AFM) in the dry state. It was found that micelles of the quaternized PB- $b$-PDMAEMAq were adsorbed onto the surface of HOPG at pH 7.0 as uniformly distributed individual objects with a broad size distribution (Fig. 2(A-C)) with the size ranging from about 50 to about $300 \mathrm{~nm}$ (with no tip convolution taken into account). An increase in the concentration of PB- $b$ PDMAEMAq used for the adsorption from $0.1 \mathrm{~g} \mathrm{~L}^{-1}$ to $5 \mathrm{~g} \mathrm{~L}^{-1}$ does not result in considerable changes of the droplet-like film morphology, although surface coverage starts to increase at a concentration of $5 \mathrm{~g} \mathrm{~L}^{-1}$. At the same time, micelles of the nonquaternized PB- $b$-PDMAEMA under the same conditions form quite different net-like structures (Fig. 2(D-F)) on the surface of HOPG. Moreover, the increase in the concentration of the copolymer from $0.1 \mathrm{~g} \mathrm{~L}^{-1}$ to $5 \mathrm{~g} \mathrm{~L}^{-1}$ leads to some increase in the surface roughness. It would suggest the increase of the average thickness of the resulting thin PB- $b$-PDMAEMA films and surface coverage as well. Taking into account all the data obtained, it is reasonable to conclude that no single micelles are visible after the direct adsorption of the micelles of both diblock copolymers onto HOPG. It seems that HOPG can induce association of the adsorbed species. The reorganization of the resultant film due to dewetting can occur as well. ${ }^{52,53}$ The most probable explanation for the different morphologies of $\mathrm{PB}-b$ PDMAEMAq and PB- $b$-PDMAEMA films is the different adhesion of the quaternized and non-quaternized copolymers to graphite and, therefore, the different ability of the films to dewet. The dewetting is especially strong for PB- $b$-PDMAEMAq films with highly charged PDMAEMAq blocks possessing low affinity to HOPG. Therefore, complete dewetting occurs, resulting in droplet morphology. At the same time, only about $50 \%$ of DMAEMA units in PB- $b$-PDMAEMA are protonated. This provides a lower extent of film dewetting due to a higher affinity of non-protonated units to HOPG. It is worth noting that once adsorbed and dried, films of both types are quite stable and do not change their morphology with time any more.

A further adsorption of an enzyme (tyrosinase) on a surface of HOPG premodified with PB- $b$-PDMAEMA or PB- $b$-PDMAEMAq was investigated by AFM (Fig. 3). It was revealed that the interaction of enzyme with a film of preadsorbed PB- $b$ PDMAEMAq diblock copolymer (the adsorption of enzyme was carried out for $10 \mathrm{~min}$ at $\mathrm{pH}$ 7.0) disturbs the droplet-like distribution of dewetted PB- $b$-PDMAEMAq film and causes the 
merging of objects (Fig. 3(A and B)). A number of small objects (with a lateral size of about $20 \mathrm{~nm}$ and height up to several $\mathrm{nm}$ ) were found on the surface as well and look like enzyme molecules directly adsorbed onto naked HOPG. The ratio of surface coverage increases only slightly. This suggests a poor interaction of enzyme with the dewetted PB- $b$-PDMAEMAq film and a weak adhesion of all objects on the surface of HOPG.

At the same time, the interaction of enzymes with a PB- $b$ PDMAEMA film on a surface of $\mathrm{HOPG}$ at $\mathrm{pH}=7.0$ takes place to a much greater extent. This interaction does not change the structure of the preadsorbed polymer film, which is still recognizable, suggesting a strong adhesion of the polymerenzyme films to the graphite surface (Fig. 3(C and D)). From the comparison of the corresponding cross-sections one can estimate the mean film thickness as $6 \pm 2 \mathrm{~nm}$ for the PB- $b$ PDMAEMA layer and $17 \pm 3 \mathrm{~nm}$ for the PB- $b$-PDMAEMA-Tyr film. This difference corresponds very well to the expected size of an enzyme globule of about $12.5 \mathrm{~nm}$, which is calculated on the basis of its molecular weight of $125 \mathrm{kDa}$.

To characterize the hydrophilic-hydrophobic properties of the resulting polymer and polymer-enzyme films, contact angle (CA) measurements were carried out for such films deposited onto HOPG and SPE. The adsorption of both the non-quaternized PB- $b$-PDMAEMA micelles and quaternized PB- $b$-PDMAEMAq micelles results in a decrease in the CA values (Table 1). It undoubtedly suggests a successful modification of both types of the graphite-based materials with the used diblock copolymers. The subsequent adsorption of tyrosinase leads to a further decrease in the CA values, thus confirming the adsorption of the enzyme and changes in the properties of the surfaces. It is interesting to note that a greater decrease in CA values is observed when tyrosinase is adsorbed onto a graphite substrate (both HOPG and SPE) premodified with PB- $b$-PDMAEMA rather than PB- $b$-PDMAEMAq. Therefore, one would expect that a larger amount of enzyme molecules is adsorbed onto the graphite substrate premodified with the non-quaternized diblock copolymer rather than with the quaternized one.

The specific enzymatic activities of the polymer-enzyme films deposited onto the SPE surfaces were determined amperometrically (the detailed measuring principle is described in the Experimental section). Similarly to the performed AFM studies, the electrochemical (amperometrical) activity of the tyrosinase-containing films (PB-b-PDMAEMAqTyr and PB- $b$-PDMAEMA-Tyr) was examined at $\mathrm{pH} 7.0$ as a function of the diblock copolymer concentration at the stage of its deposition. A pronounced (more than 10-fold) increase in the enzymatic activity of the PB- $b$-PDMAEMA-Tyr films was observed with a rising concentration of the copolymer solution from $0.1 \mathrm{~g} \mathrm{~L}^{-1}$ to $10 \mathrm{~g} \mathrm{~L}^{-1}$ (Fig. 4). Contrary to this, there was no considerable increase in the enzymatic activity of the PB- $b$ PDMAEMAq-Tyr films with rising concentration of PB- $b$ PDMAEMAq in solution (Fig. 4). The obtained results are in good agreement with the AFM results and CA data. Actually, the enzymatic activity is usually determined by the enzymatic parameters $K_{\mathrm{M}}$ and $V_{\max }$ of the Michaelis-Menten equation. According to our previously published data on similar systems, $V_{\text {max }}$, but not $K_{\mathrm{M}}$, is sensitive to the type of polyelectrolyte used ${ }^{54}$ and the conditions of its deposition, therefore, most probably the observed effect of $V_{\max }$ increase $\left(V_{\max }=E_{0} \times k_{\text {cat }}\right)$ could be caused by the increase in concentration of the enzyme active form on the surface, rather than by the increase of the catalytic constant $\left(k_{\text {cat }}\right)$ of the adsorbed enzyme. ${ }^{19}$ Therefore, our new results strongly suggest that the specific enzymatic activities of the polymer-enzyme films are, first of all, determined by the amount of the adsorbed enzyme, which is controlled by the structure/morphology of the preadsorbed polymer layer, its thickness, the coverage of the original surface of the conductive substrate as well as by the strength of the polymer attachment to the substrate surface.

\section{Surface assembly of diblock copolymer-enzyme films: the effect of $\mathbf{p H}$}

To clarify the role of charges on the interaction of the diblock copolymer micelles with a graphite surface, the effect of $\mathrm{pH}$ on solution behavior of PB- $b$-PDMAEMA and its adsorption onto a graphite surface was examined starting from a completely charged state of the PDMAEMA block at $\mathrm{pH} 3.0$ to its completely uncharged state at $\mathrm{pH} 10.0\left(\mathrm{p} K_{\mathrm{b}, \text { app }}\right.$ for PDMAEMA is $c a .7 .8$ (ref. 48)). According to the cryo-TEM data (Fig. 5(A-D)), PB-bPDMAEMA self-assembles into micelles in the whole $\mathrm{pH}$ range studied. These micelles are protonated at $\mathrm{pH} 3.0$ and, therefore, look very similar to the charged micelles of the quaternized analogue. They have a PB core and a partly visible PDMAEMA corona. The lower the protonation degree of the micelles, the larger their size is. It is worthy to note that the micelles are close to their precipitation state at $\mathrm{pH} 10.0$, which is clearly seen from a cryo-TEM image (Fig. 5(D)). Then, adsorption of the micelles at different $\mathrm{pH}$ was examined by AFM. It was found that protonated PB- $b$-PDMAEMA micelles adsorbed under acidic conditions (at pH 3.0) result in similar film structure as it was found for a film of charged micelles of PB- $b$-PDMAEMAq. The AFM image (Fig. 5(E)) exhibits uniformly distributed spherical objects that look like a completely dewetted film. ${ }^{52}$ Increasing the $\mathrm{pH}$ to 6.0 leads to an enlargement of the spherical objects (Fig. 5(F)), which all merge at $\mathrm{pH}$ values higher than 7.0 (Fig. 5(G and $\mathrm{H})$ ), thereby forming continuous films with a high surface coverage. Thus, a variation of $\mathrm{pH}$ changing the charge of the PB- $b$-PDMAEMA micelles can influence their interaction with a surface of HOPG. Indeed, it results in quite a different morphology of the formed polymer films despite the fact that in aqueous solution both PB- $b$-PDMAEMA and PB- $b$-PDMAEMAq form self-assemblies of micellar (core-corona) type. Therefore, it is expected that strongly attached condensed PB- $b$-PDMAEMA films adsorbed at $\mathrm{pH}>7.0$ can potentially bind more enzyme molecules at the subsequent enzyme adsorption stage.

This inference is proven by measurements of the enzymatic activities of the polymer-enzyme films as a function of $\mathrm{pH}$ of the PB- $b$-PDMAEMA deposition solution. Two types of polymerenzyme films attached to SPE were studied. One comprises tyrosinase as an enzyme (PB- $b$-PDMAEMA-Tyr) and served as a biosensor surface for phenol. The second system includes choline oxidase as an enzyme (PB- $b$-PDMAEMA-ChO) and served as a biosensor surface for choline. The measuring 

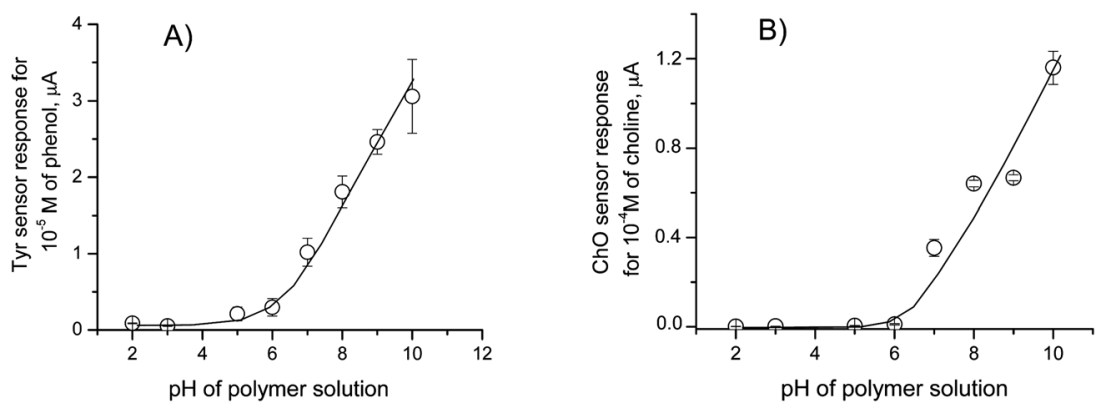

Fig. 6 Enzymatic (electrochemical) activity of the PB- $b$-PDMAEMA-Tyr (A) and PB- $b$-PDMAEMA-ChO (B) films versus the pH of the PB- $b$-PDMAEMA solution, at which its adsorption was carried out. Adsorption of the copolymer: $5 \mathrm{~g} \mathrm{~L}^{-1}$ PB-b-PDMAEMA solution in buffers $\mathrm{pH} 2 \div 10$ for $1 \mathrm{~h}$. Adsorption of tyrosinase: $2 \times 10^{-4} \mathrm{M}$ solution in $0.05 \mathrm{M}$ of sodium phosphate $(\mathrm{pH} 7.0)$ for $10 \mathrm{~min}$. Adsorption of choline oxidase: $1 \times 10^{-4} \mathrm{M}$ solution in $0.05 \mathrm{M}$ of HEPES with $0.03 \mathrm{M}$ of potassium chloride (pH 7.5) for $10 \mathrm{~min}$. Lines through the experimental points are drawn only as guides for the eye.

principles of both biosensors are given in the Experimental section (Scheme 1). A pronounced increase in the enzymatic activities of both tyrosinase and choline oxidase was observed with the increasing $\mathrm{pH}$ of the diblock copolymer deposition from 2.0 to 10.0 (Fig. 6(A and B)). Comparing the results on the enzymatic activity with the obtained AFM data revealing the film morphology (Fig. 5(E-H)), one can infer that a pH-dependent formation of the PB- $b$-PDMAEMA film results in a higher surface coverage by the diblock copolymer at higher $\mathrm{pH}$ due to
(A)

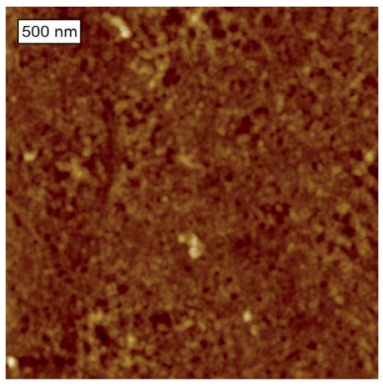

(B)

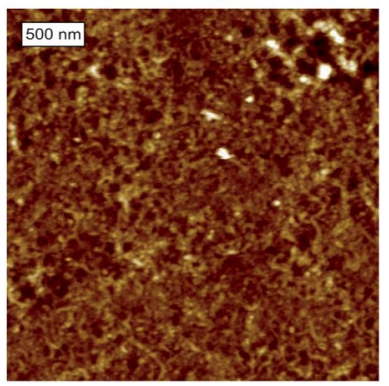

Fig. 7 The $3 \times 3 \mu \mathrm{m}$ AFM height image of a PB- $b$-PDMAEMA-Tyr film in the dry state (A) and under liquid (B). The AFM image was taken for the same sample in the liquid cell AFM mode in $\mathrm{pH} 7.0$ buffer. The time for the diblock copolymer and the enzyme adsorption was $1 \mathrm{~h}$ and $10 \mathrm{~min}$, respectively. The concentration of the copolymer was $5 \mathrm{~g} \mathrm{~L}^{-1}$, the concentration of the enzyme was $2 \times 10^{-4} \mathrm{M}$. The height range was $50 \mathrm{~nm}$. an increasing affinity of non-quaternized PB- $b$-PDMAEMA to a graphite-based material with the decreasing protonation of PDMAEMA blocks. This conclusion is additionally confirmed by data on CAs measured for PB- $b$-PDMAEMA adsorbed onto SPEs. A monotonous decrease in CA values from $95^{\circ}$ to $80^{\circ}$ was observed in the $\mathrm{pH}$ range 3.0 to 10.0 .

The operating conditions of the biosensors imply that they must stay under liquid for relatively long periods of time. Therefore, the stability of the film structure becomes an important issue. We comparatively examined the morphology of the PB- $b$-PDMAEMA-Tyr film in air and under liquid (Fig. 7(A and B)). These films showed a remarkably high stability, since no significant changes in morphology were observed even after a period of $1.5 \mathrm{~h}$ of constant immersion in buffer, as was examined by repeated scanning of the same area in 30 min time intervals (see the ESI + ).

\section{Characterisation of biosensors}

Finally, the most active copolymer-enzyme films were formed on an SPE surface with PB- $b$-PDMAEMA adsorbed at pH 10 at a polymer concentration of $5 \mathrm{~g} \mathrm{~L}^{-1}$. Their activity and stability were measured and compared to already existing setups. The operation stability of the biosensor coatings was evaluated for $>10$ repeated measurements at a standard analyte concentration. It can be characterized quantitatively as a percentage of the analytical signal change per a single measurement and can be calculated according to the formula: $\Delta I=100 \% \times \operatorname{tg} I / I_{1}$, where

Table 2 The comparative activity and stability of sensor coatings

\begin{tabular}{|c|c|c|c|}
\hline System & $\begin{array}{l}\text { Polymer concentration, } \\
\mathrm{g} \mathrm{L}^{-1}(\mathrm{pH})\end{array}$ & $\begin{array}{l}\text { Response to standard } \\
\text { analyte concentration }{ }^{c}, \mathrm{nA}\end{array}$ & Stability of response ${ }^{d}, \%$ \\
\hline \multirow[t]{2}{*}{ PB- $b$-PDMAEMA-Tyr } & $5.0(\mathrm{pH} \mathrm{10})$ & $3058 \pm 481$ & -0.11 \\
\hline & $5.0(\mathrm{pH} 7)$ & $1028 \pm 131$ & -0.16 \\
\hline PDADMAC-Tyr $^{a}$ (ref. 55) & $5.0(\mathrm{pH} 7)$ & $905 \pm 90$ & $-0.6 \pm 0.2$ \\
\hline PB- $b$-PDMAEMA-ChO & $5.0(\mathrm{pH} 10)$ & $1160 \pm 74$ & $-1.0 \pm 0.3$ \\
\hline$(\mathrm{PDADMAC}-\mathrm{PAS})_{2}(\mathrm{PDADMAC}-\mathrm{ChO})_{3}{ }^{b}$ (ref. 47$)$ & $5.0(\mathrm{pH} 7)$ & $570 \pm 100$ & $-2.0 \pm 0.7$ \\
\hline
\end{tabular}

${ }^{a}$ PDADMAC - poly(diallyldimethylammonium chloride). ${ }^{b}$ PAS - poly(anetholsulfonate, sodium salt). ${ }^{c}$ Response to $10^{-5} \mathrm{M}$ of phenol for tyrosinase sensor and to $10^{-4} \mathrm{M}$ of choline for choline oxidase sensor. ${ }^{d} \Delta I=100 \% \times \operatorname{tg} I / I_{1}$, wherein $\operatorname{tg} I$ is the slope of the dependence of the analytical signal on the number of repeat measurements, normalized to the initial analytical signal $I_{1}$ and expressed in percentage. 
$\operatorname{tg} I$ is the slope of the dependence of the analytical signal on the number of repeated measurements normalized to the initial analytical signal $I_{1}$ and given in percentage (details are in the ESI $\dagger$ ). The data clearly indicate (Table 2) that the use of the diblock copolymer as a component for biosensor coatings allows one to achieve a 2-3-fold increase in biosensor sensitivity in comparison with the former biosensor coatings composed of the same enzymes and linear homopolyelectrolytes under similar conditions. Additionally, the operation stability of the biosensor coatings based on diblock copolymer micelles improves by a factor of $c a$. 2-3 as well. These results demonstrate, for the first time, a high potential of the use of micelleforming polymers for the construction of polymer-enzyme biosensor coatings with considerably improved enzymatic activity and enhanced operation stability.

\section{Conclusions}

We demonstrate that micelles of diblock copolymers to be adsorbed under the appropriate conditions can result in a homogeneous (on micron length-scale) surface coverage by the diblock copolymer, which subsequently can bind a large number of active enzyme molecules at the subsequent enzyme adsorption stage. Therefore, we offer an effective way for the non-covalent and non-destructive immobilization of enzymes. This finding can have a specific practical value for surface modification techniques applicable amongst others for biosensor design.

The use of the non-quaternized PB- $b$-PDMAEMA as the polymeric component of the biosensor coatings, the application of specified adsorption conditions for its deposition (at least $\mathrm{pH}>$ 7.0), and a subsequent modification with tyrosinase or choline oxidase for phenol and choline assays, respectively, allowed us to achieve more than a 3-fold increase in biosensor sensitivity for the phenol assay and a 2-fold increase for the choline assay compared to our best results obtained so far. The operational stability of the biosensors was also improved in the same proportion. This demonstrates an obvious advantage of such polymer-enzyme coatings in comparison with the earlier developed and optimized biosensor coating based on linear poly(diallyldimethylammonium chloride), ${ }^{\mathbf{1 9}, 54-57}$ which was found to be one of the best and the most frequently used among polyelectrolytes used for the construction of LbL biosensor coatings.

To expand the understanding of the formation of nanosized coatings with macromolecules of ionic amphiphilic diblock copolymers and their interaction with biologically active species, the chemical nature of hydrophobic blocks of ionic amphiphilic diblock copolymers as well as their hydrophobic-hydrophilic balance given by a ratio of lengths of hydrophobic and ionic blocks should be studied and compared to linear analogues as well. This will be the subject of our further research.

\section{Acknowledgements}

This research was supported by the Deutsche Forschungsgemeinschaft (DFG) within Sonderforschungsbereich "Von partikulären Nanosystemen zur Mesotechnologie" (SFB 840), Russian Foundation for Basic Research (RFBR, grant no. 11- 03-00712-a), Lomonosov Moscow State University Programme of Development; and Lomonosov Moscow State University postgenomic programme. C.V. Synatschke acknowledges funding through a BayEFG scholarship as well as support from the Elite Network of Bavaria (ENB). Dr J. Gensel, M. Pretzl and M. Hund are gratefully acknowledged for their help with the AFM measurements.

\section{References}

1 R. K. Iler, J. Colloid Interface Sci., 1966, 21, 569-594.

2 G. Decher, J. D. Hong and J. Schmitt, Thin Solid Films, 1992, 210-211, 831-835.

3 G. Decher and J. Schmitt, Prog. Colloid Polym. Sci., 1992, 89, 160-164.

4 G. Decher, Science, 1997, 277, 1232-1237.

5 D. Lee, M. F. Rubner and R. E. Cohen, Nano Lett., 2006, 6, 2305-2312.

6 J. H. Cho, J. K. Hong, K. Char and F. Caruso, J. Am. Chem. Soc., 2006, 128, 9935-9942.

7 N. Ma, Y. P. Wang, Z. O. Wang and X. Zhang, Langmuir, 2006, 22, 3906-3909.

8 K. Emoto, M. Iijima, Y. Nagasaki and K. Kataoka, J. Am. Chem. Soc., 2000, 122, 2653-2654.

9 Z. C. Zhu and S. A. Sukhishvili, J. Mater. Chem., 2012, 22, 7667-7671.

10 J. Gensel, I. Dewald, J. Erath, E. Betthausen, A. H. E. Müller and A. Fery, Chem. Sci., 2013, 4, 325-334.

11 V. V. Tsukruk, Adv. Mater., 1998, 10, 253-257.

12 A. J. Khopade and F. Caruso, Nano Lett., 2002, 2, 415418.

13 A. A. Mamedov, N. A. Kotov, M. Prato, D. M. Guldi, J. P. Wicksted and A. Hirsh, Nat. Mater., 2002, 1, 190-194.

14 Y. Lvov, K. Ariga, I. Ichinose and T. Kunitake, J. Am. Chem. Soc., 1995, 117, 6117-6123.

15 G. Ladam, P. Schaaf, F. J. G. Cuisiner, G. Decher and J.-C. Voegel, Langmuir, 2001, 17, 878-882.

16 J. R. Siquei Jr, L. Caseli, F. N. Crespilho, V. Zucolotto and O. N. Oliveira, Biosens. Bioelectron., 2010, 25, 1254-1263.

17 F. N. Crespilho, V. Zucolotto, O. N. Oliveira and F. C. Nart, Int. J. Electrochem. Sci., 2006, 1, 194-214.

18 I. Varga, A. Mezei, R. Meszaros and P. M. Claesson, Soft Matter, 2011, 7, 10701-10712.

19 M. S. Gromova, L. V. Sigolaeva, M. A. Fastovets, E. G. Evtushenko, I. A. Babin, D. V. Pergushov, S. V. Amitonov, A. V. Eremenko and I. N. Kurochkin, Soft Matter, 2011, 7, 7404-7409.

20 G. Decher and J. B. Schlenoff, Multilayer Thin Films, WileyVCH, New York, 2003.

21 W. Li, Z. Wang, C. Sun, M. Xian and M. Zhao, Anal. Chim. Acta, 2000, 418, 225-232.

22 S. Komathi, A. I. Gopalan and K.-P. Lee, Biosens. Bioelectron., 2009, 24, 3131-3134.

23 Y. Kobayashi, T. Hoshi and J. Anzai, Chem. Pharm. Bull., 2001, 49(6), 755-757.

24 N. Ferreyra, L. Coche-Guerente and P. Labbe, Electrochim. Acta, 2004, 49, 477-484. 
25 D. Trau and R. Renneberg, Biosens. Bioelectron., 2003, 18, 1491-1499.

26 M. K. Ram, P. Bertoncello, H. Ding, S. Paddeu and C. Nicolini, Biosens. Bioelectron., 2001, 16, 849-856.

27 J. Wang, G. Liu and Y. Lin, Analyst, 2006, 131, 477-483.

28 H. Shi, Z. Song, J. Huang, Y. Yang, Z. Zhao, J. Anzai, T. Osa and Q. Chen, Mater. Sci. Eng., C, 2005, 25, 433-435.

29 X. Qin, H. Wang, X. Wang, S. Li, Z. Miao, N. Huang and Q. Chen, Mater. Sci. Eng., C, 2009, 29, 1453-1457.

30 H. Shi, Y. Yang, J. Huang, Z. Zhao, X. Xu, T. Osa and Q. Chen, Talanta, 2006, 70, 852-858.

31 G. Liu and Y. Lin, Anal. Chem., 2006, 78, 835-843.

32 S. Campuzano, B. Serra, M. Pedrero, F. J. Manuel de Villena and J. M. Pingarrón, Anal. Chim. Acta, 2003, 494, 187-197.

33 L. Coche-Guerente, P. Labbé and V. Mengeaud, Anal. Chem., 2001, 73, 3206-3218.

34 E. S. Forzani and V. M. Solís, Anal. Chem., 2000, 72, 5300-5307.

35 E. S. Forzani, M. L. Teijelo, F. Nart, E. J. Calvo and V. M. Solís, Biomacromolecules, 2003, 4, 869-879.

36 S. Förster, V. Abetz and A. H. E. Müller, Adv. Polym. Sci., 2004, 166, 173-210.

37 M. R. Talingting, Y. H. Ma, C. Simmons and S. E. Webber, Langmuir, 2000, 16, 862-865.

38 G. B. Webber, E. J. Wanless, S. P. Armes, F. L. Baines and S. Biggs, Langmuir, 2001, 17, 5551-5561.

39 G. B. Webber, E. J. Wanless, V. Bütün, S. P. Armes and S. Biggs, Nano Lett., 2002, 2, 1307-1313.

40 G. B. Webber, E. J. Wanless, S. P. Armes, Y. Q. Tang, Y. T. Li and S. Biggs, Adv. Mater., 2004, 16, 1794-1798.

41 I. W. Hamsley, S. D. Conell and S. Collins, Macromolecules, 2004, 37, 5337-5351.

42 V. M. De Cupere, J.-F. Gohy, R. Jérome and P. G. Rouxhet, J. Colloid Interface Sci., 2004, 271, 60-68.

43 K. Sakai, E. G. Smith, G. B. Webber, M. Baker, E. J. Wanless, V. Bütün, S. P. Armes and S. Biggs, J. Colloid Interface Sci., 2007, 314, 381-388.
44 K. Sakai, E. G. Smith, G. B. Webber, M. E. J. Wanless, V. Bütün, S. P. Armes and S. Biggs, J. Colloid Interface Sci., 2006, 303, 372-379.

45 C. Auschra and R. Stadler, Polym. Bull., 1993, 30, 257264.

46 C. V. Synatschke, F. H. Schacher, M. Förtsch, M. Drechsler and A. H. E. Müller, Soft Matter, 2011, 7, 1714-1725.

47 E. A. Dontsova, Y. S. Zeifman, I. A. Budashov, A. V. Eremenko, S. L. Kalnov and I. N. Kurochkin, Sens. Actuators, B, 2011, 159, 261-268.

48 F. A. Plamper, M. Ruppel, A. Schmalz, O. Borisov, M. Ballauff and A. H. E. Müller, Macromolecules, 2007, 40, 8361-8366.

49 O. V. Borisov, E. B. Zhulina, F. A. M. Leermakers and A. H. E. Müller, Adv. Polym. Sci., 2011, 241, 57-129.

50 J. Gensel, E. Betthausen, C. Hasenöhrl, K. Trenkenschuh, M. Hund, F. Boulmedais, P. Schaaf, A. H. E. Müller and A. Fery, Soft Matter, 2011, 7, 11144-11153.

51 J. Gensel, T. Borke, N. Pazos-Pérez, A. Fery, D. V. Andreeva, E. Betthausen, A. H. E. Müller, H. Möhwald and E. V. Skorb, Adv. Mater., 2012, 24, 985-989.

52 D. Yan, H. Huang, T. He and F. Zhang, Langmuir, 2011, 27, 11973-11980.

53 G. Reiter, Phys. Rev. Lett., 1992, 68, 75-78.

54 G. V. Dubacheva, M. V. Porus, L. V. Sigolaeva, D. V. Pergushov, D. R. Tur, V. S. Papkov, A. B. Zezin, A. A. Yaroslavov, A. V. Eremenko, I. N. Kurochkin and S. D. Varfolomeev, Nanotechnol. Russ., 2008, 3, 221-227.

55 M. S. Gromova, A. V. Kondrashina, A. V. Eremenko, L. V. Sigolaeva, D. V. Volkov, N. I. Zhuravleva and I. N. Kurochkin, Tekhnologii zhivikh sistem, 2012, 9, 33-40.

56 L. V. Sigolaeva, A. Makower, A. V. Eremenko, G. F. Makhaeva, V. V. Malygin, I. N. Kurochkin and F. Scheller, Anal. Biochem., 2001, 290, 1-9.

57 L. Sigolaeva, G. Makhaeva, E. Rudakova, N. Boltneva, M. Porus, G. Dubacheva, A. Eremenko, I. Kurochkin and R. J. Richardson, Chem.-Biol. Interact., 2010, 187, 312-317. 